\title{
Eulálio Motta: um panfletário no sertão da Bahia
}

\author{
[ Eulálio Motta: a panfletary in the backlands of Bahia
}

\section{Patrício Nunes Barreiros ${ }^{\mathrm{I}}$}

Pesquisa vinculada ao projeto Edição das Obras de Eulálio Motta, com financiamento da Fundação de Amparo à Pesquisa do Estado da Bahia (Fapesb) e do Conselho Nacional de Desenvolvimento Científico e Tecnológico (CNPq).

RESUMO - O objetivo deste artigo é apresentar a ação panfletária de Eulálio Motta, destacando a produção, circulação e recepção de panfletos no sertão da Bahia. Apesar de sua ação panfletária ter se estendido por mais de 60 anos, o acervo do escritor contém apenas 57 desses impressos. Esses textos revelam importantes características da história cultural das práticas de escrita e de leitura do sertão baiano, envolvendo a ação do panfletário e suas relações com os donos de tipografias e autoridades políticas. A correspondência de Eulálio Motta, seus diários, manuscritos, datiloscritos, dentre outros documentos, são utilizados como fontes para compreender a sua ação panfletária • PALAVRAS-CHAVE - Panfletos; Eulálio Motta; sertão baiano. • ABSTRACT - The objective of this article is to present the pamphletary action of Eulálio Motta, highlighting the production, circulation and reception of leaflets in the backlands of Bahia. Although his pamphlet action has been extended for more than 60 years, the writer's collection contains only 57 of these printed. These texts reveal important characteristics of the cultural history of the writing and reading practices backlands of Bahia, involving the action of the pamphleteer and his relations with the owners of typographies and political authorities. The correspondence of Eulálio Motta, his diaries, manuscripts, and dactyloscripts, among other documents, are used as sources to understand his pamphlet action. KEYWORDS · Pamphlets; Eulálio Motta; backlands of Bahia.

Recebido em I9 de abril de 2017

Aprovado em 4 de agosto de 2017

BARREIROS, Patrício Nunes. Eulálio Motta: um panfletário no sertão da Bahia. Revista do Instituto de Estudos Brasileiros, Brasil, n. 67, p.57-80, ago. 2017.

DOI: http://dx.doi.org/Io.II606/issn.23I6-90IX.voi67p57-80

I Universidade Estadual de Feira de Santana (UEFS, Feira de Santana, BA, Brasil). 
Os panfletos do escritor baiano Eulálio Motta (I907-I988) constituem um conjunto de textos de temáticas variadas, impressos em apenas uma folha, publicados no município de Mundo Novo (BA), entre as décadas de I930 e I980. No acervo do escritor, foram preservados 57 desses textos, mas, ao longo de mais de 60 anos, o escritor publicou centenas deles. Por meio dos panfletos, Eulálio Motta exerceu grande influência política na região de Mundo Novo, sendo responsável por inúmeras polêmicas que desencadearam debates memoráveis.

Esses textos têm características panfletárias que, segundo Marc Angenot ${ }^{2}$, podem ser notadas pelo tom do discurso político, das críticas mordazes, da ironia, da caricatura, da exaltação das qualidades morais ou literárias do panfletário e dos aspectos gráficos e materiais dos impressos. Os fragmentos destacados a seguir evidenciam algumas características do discurso panfletário desses textos:

Tenha ou não tenha jeito, precisamos gritar, escrever, publicar, escandalizar!3.

[...] eu gostaria de me dirigir a você com palavras brandas, palavras de concórdia e de paz; ou, pelo menos, adotar o silêncio num esforço para algum possível perdão. Mas com o seu conhecido espírito de ódio, e rancor, de vingança, de inconformismo com a derrota, agredindo os homens mais representativos da sociedade mundo-novense, com o xingamento de caluniadores, não é possível a paz. Só nos resta, pois, transformar a nossa pena em máquina fotográfica para fotografar e exibir em crônicas como esta, as podridões marcantes de sua passagem pelo poder em nosso município, para grande vergonha desta terra4.

Desde o século XIX, no contexto brasileiro, as palavras panfleto e pasquim passaram a ser empregadas como sinônimas, mas, durante o Estado Novo, panfleto e panfletário adquiriram sentido pejorativo, sendo associados a atos subversivos ligados às ações dos comunistas. Eulálio Motta foi integralista e combatente contra

2 ANGENOT, Marc. La parole pamphlétaire: typologie des discurs modernes. Paris: Payot, I982.

3 MOTTA, Eulálio de Miranda. Viva a esperança!. Panfleto. Mundo Novo, I7 de outubro de I966.

4 Idem. Podridão!!. Panfleto. Mundo Novo, 22 de abril de I967. 
o comunismo. Por esse motivo, talvez, tenha preferido autointitular-se pasquineiro em lugar de panfletário.

Ele também utilizou a expressão "escriba da roça" para referir-se a sua ação panfletária. Definir-se como "da roça” foi uma estratégia retórica de Eulálio Motta para marcar o seu locus discursivo no ambiente rural, a roça. Com a valorização da vida urbana, entendida como sinônimo de prosperidade e progresso, as palavras "campo", "rural" e, principalmente, "roça" assumiram conotações pejorativas e foram associadas a lugares atrasados, longe da civilização. Por isso, o qualificativo "da roça" utilizado para caracterizar pasquineiro e escriba é bastante elucidativo, correspondendo a uma estratégia discursiva de Eulálio Motta. No panfleto Fim de papo, Eulálio Motta esboçou uma oposição clara entre o escriba "da roça" e os homens eminentes "da cidade", confirmando que o campo é de fato o locus enunciativo do seu discurso panfletário. Segue o fragmento do panfleto Fim de papo: "Muito pesado, amigo, é o regime a que se refere mensagem assinada por homens eminentes [membros da diretoria da Associação Brasileira de Medicina e Associação de Médicos da Bahia] e não por um 'mero escriba da roça' [...]"’.

Eulálio Motta não era um "mero escriba da roça”, apesar de morar na zona rural. A fazenda Morro Alto estava longe de ser uma "roça", indiferente ao progresso das cidades. Através de um gerador de energia elétrica alimentado a diesel, dispunha-se de lâmpadas, de rádio e de televisão, havia geladeira e fogão movidos a gás, água na torneira, chuveiro e, na garagem, havia um Jeep Willys modelo I950. Além disso, Eulálio Motta tinha formação em nível superior, com grande erudição acadêmica. Portanto, ele não era diferente dos "homens eminentes" da cidade, confirmando que o qualificativo "da roça” é de fato uma estratégia retórica do escritor.

A ação panfletária de Eulálio Motta em Mundo Novo rompe o paradigma que separa o campo da cidade, o interior dos grandes centros. O pasquineiro da roça mostra-se atualizado com o seu tempo, e a sua atuação como escritor demonstra que o texto impresso fazia parte do cotidiano das pequenas cidades, vilas e roças do interior da Bahia.

Diferente dos livros, os panfletos não são feitos para durar, para serem guardados em estantes. Eles também não são escritos com vistas ao comércio; suas motivações são de ordem político-ideológica e têm finalidade prática específica. Não contam com uma indústria editorial ávida por lucro e, por isso, não deram origem às práticas comerciais que mobilizaram o comércio de papel, as livrarias, os polêmicos copyrights. Talvez isso tenha acontecido porque, materialmente, o panfleto é efêmero, mas apenas materialmente. Seus efeitos não o são. Eles são capazes de mobilizar multidões, interferir na opinião pública e, com isso, mudar o curso da história.

Os panfletos são feitos para atuar num determinado momento, para atingir um alvo e, por isso mesmo, circulam rapidamente, driblando a censura, impondo-se na sociedade, como uma cisão, um corte no statu quo, rompendo a ética do que pode ser dito. Além disso, por suas características materiais (impressos em apenas uma folha), eles eram rapidamente produzidos em tipografias estabelecidas legalmente nas comunidades, mas também nas oficinas tipográficas clandestinas instaladas em

5 Idem. Fim de papo. Panfleto. Mundo Novo, Io de julho de 1982. 
porões escuros. Muitas vezes, os panfletos eram confeccionados a partir de métodos artesanais, utilizando pequenos mimeógrafos escolares ou por meio de técnicas alternativas de impressão, motivadas pelas mais diversas circunstâncias.

Essas particularidades materiais dos panfletos, suas dimensões e formas (tamanhos, cores e layouts) produzem sentidos e estão relacionadas às práticas sociais e aos usos que se fazem deles nos mais diferentes contextos.

Pode-se dizer, portanto, que existem práticas culturais peculiares aos panfletos, porque eles não são escritos, impressos, lidos e usados da mesma forma que os livros, as revistas, os jornais e seus congêneres, por isso, eles reclamam sua própria história (ou histórias). Nesse sentido, concorda-se com Roger Chartier ${ }^{6}$ quando diz que é preciso buscar compreender como as obras estão amparadas na "cultura gráfica" de seu tempo, aproximando o que a tradição ocidental separou durante muito tempo: de um lado, a compreensão e o comentário das obras; de outro, a análise das condições técnicas ou sociais de sua publicação, circulação e apropriação.

Os significados dos textos não residem apenas na estrutura verbal que os compõem; os elementos não verbais relacionados à materialidade, os aspectos gráficos, tipográficos, as marcas inseridas no papel, as manchas, o modo como são preservados, guardados, usados, lidos, as técnicas de impressão, as peculiaridades da sua distribuição, tudo isso integra a sua sócio-história e interfere nos seus sentidos.

A literatura panfletária de Eulálio de Miranda Motta tem origem em suas convicções político-ideológicas, que ele classificou de "orientação doutrinária", e remonta ao início da década de I930, quando se tornou integralista.

O primeiro texto no qual Eulálio Motta apresentou um tom deliberadamente panfletário, assumindo o lugar de militante em favor de um ideal político, foi publicado no jornal O Lidador, da cidade de Jacobina (BA), em 29 de dezembro de I933:

Eu nunca fui político. Nunca pertenci a esse ou aquele partido [...] e nunca fui partidário porque em todo partido eu via os conchavos indecentes, os acordos, camaradagens, lutas vergonhosas pelos cargos, os choques de interesses pessoais, os fuxicos, as intrigas, as rixas, o despudor, a falta de vergonha e o desinteresse completo pelo Brasil. [...] Meu caráter reto e puro não se faz para curvar-se e enlamear-me nas porcarias dos politiqueiros. Entre o meu caráter e o caráter dos partidos, há uma diferença de branco para o preto. Era impossível adaptação. Eu, entretanto, moço [...], procurava um caminho para seguir. Foi isso que me levou a leitura dos livros sobre comunismo. [...] No comunismo encontrei ideal porque no comunismo há ideal. Era a primeira vez que eu encontrava um ideal. Natural, portanto, que eu me fizesse escravo dele. Agora, porém, que surge este Sol que é o Integralismo, este movimento formidável que está impregnando toda a mocidade do Brasil; agora, que o Integralismo surge mostrando com inteligência, com cultura [...] o fracasso completo da Liberal Democracia e os abusos do ideal comunista, não me era possível "ficar onde estava”. Errar é humano. Permanecer no erro, por capricho pessoal, é estupidez. E a estupidez é própria dos burros. E eu não sou burro. Por isso é que [...] passei para o campo do combate ao

6 CHARTIER, Roger. Inscrever e apagar: cultura escrita e literatura. Tradução de Luzmara Curcino Ferreira. São Paulo: Unesp, 2007, p. II. 
comunismo. Sou integralista por uma questão de inteligência, de sinceridade. E pelo integralismo lutarei até o fim, com desinteresse de minha própria vida! No integralismo só há um interesse - o Brasil. O Integralismo há de arrancar o Brasil das garras dos politiqueiros inconscientes! O integralismo salvará o Brasil, custe o que custar. Se o integralismo não salvar o Brasil, o comunismo matará o Brasil [...]7.

Foi como militante integralista que Eulálio Motta estabeleceu o seu discurso panfletário mantendo-se fiel aos ideais da AIB (Ação Integralista Brasileira), mesmo depois do seu fechamento em I937. Ainda que, em alguns momentos, tenha renunciado aos princípios do integralismo em detrimento de seu próprio benefício, o discurso panfletário de Eulálio Motta é marcado por extremo conservadorismo.

Imbuído desses ideais, ele se investiu de uma verdade utópica, redentora e, como todo panfletário, partiu para o combate, disposto a lutar por sua ideologia, até as últimas consequências. O texto publicado no jornal O Lidador em I933 é um divisor de águas, porque, antes disso, a atuação de Eulálio Motta na imprensa restringia-se à publicação de poemas, de textos humorísticos, de crônicas sobre temas do cotidiano e de comentários de leituras, sem assumir uma posição político-ideológica deliberada, como o fez a partir da publicação do referido texto no jornal $O$ Lidador.

Apesar de demonstrar simpatia ao comunismo e ter se declarado ateu, desencadeando problemas familiares, na década de I920, Eulálio Motta não se tornou um militante comunista. Ao se converter ao integralismo, ele se lançou como combatente fervoroso em favor da AIB, assumindo suas convicções publicamente. $\mathrm{O}$ jornal O Lidador, em sua edição de 3I de janeiro de I934, publicou um texto assinado pelo seu proprietário, Nemésio Lima, intitulado "Phco. Eulálio Mota Integralista de convicções":

[...] O nosso talentoso colaborador e grande amigo, Farmacêutico Eulálio Mota, realizou, em Mundo Novo, onde ele é geralmente estimado, duas empolgantes conferências sobre o Integralismo [...] a última conferência teve lugar a 25 do pretérito e dela destacamos os trechos em que o destemido integralista se refere a politicagem local. [Palavras de Eulálio Motta transcritas] [...] É natural que os homens de uma terra onde não viu a luz viverem na escuridão [...] Meus amigos: olhais a politicagem e olhai-vos. Vereis que politicagem só produz ódio. [...] Eu vos prego: abri os olhos à luz! Vêde! [...] ${ }^{8}$.

Observa-se que Eulálio Motta apresenta as suas ideias como uma verdade luminosa capaz de dissipar a escuridão da ignorância, e seu discurso tem um tom profético, típico dos panfletários. Entre I933 e I936, Eulálio Motta publicou vários textos no jornal O Lidador, fazendo apologia do integralismo, combatendo o comunismo e discorrendo sobre os aspectos ideológicos que sustentavam a doutrina de Plínio Salgado, apoiando-se em princípios filosóficos e históricos.

7 MOTTA, Eulálio de Miranda. O integralismo vencerá. O Lidador, Jacobina, p. I, 29 de dezembro de 1933. Manteve-se a grafia original.

8 LIMA, Eudaldo. Phco. Eulálio Mota Integralista de convicções. O Lidador, Jacobina, p. I, 3 I de janeiro de I934. Foi mantida a grafia original. 
Os integralistas incentivavam a realização de palestras e a publicação de prospectos instrutivos para fazer propaganda de suas ideias. Assim, entre I933 e I936, Eulálio Motta publicou panfletos com orientações acerca dos princípios do integralismo e os distribuiu nos povoados, distritos, fazendas e sedes dos municípios de Jacobina, Mundo Novo e Miguel Calmon.

A partir de I936, os integralistas foram perseguidos e hostilizados na Bahia. A situação se agravou mais ainda quando Getúlio Vargas proibiu o funcionamento da Ação Integralista Brasileira em I937. E, como era de esperar, as portas da maioria dos jornais se fecharam para aqueles que ainda sustentavam suas convicções e juravam fidelidade ao Sigma.

Durante o Estado Novo, qualquer ideia contrária ao governo era um ato subversivo. Assim, um jornal como O Lidador não poderia medir forças com o poder instituído. Qualquer deslize seria o fim, poderia resultar no fechamento do jornal e até mesmo na prisão de seus responsáveis. Então, Eulálio Motta, o integralista de convicção, como o definiu Nemésio Lima, não mais publicaria seus textos nos jornais até o fim do Estado Novo e a reabertura dos partidos políticos, em I945.

Nem mesmo os poemas de Eulálio Motta eram publicados, porque seu nome estava totalmente atrelado ao integralismo, que vivia uma fase de intensa depreciação, tanto por parte do governo, quanto por parte dos comunistas, que associavam o integralismo ao nazismo e ao fascismo. Os desdobramentos da Segunda Guerra Mundial não favoreceram os ex-integralistas, aumentando ainda mais a hostilidade contra eles, colocando-os como uma ameaça nacional. Até mesmo Nemésio Lima, amigo e conterrâneo de Eulálio Motta, negou-se a publicar seus textos, ainda que esses, aparentemente, não tivessem teor político-partidário. Eulálio Motta reagiu à negativa de Nemésio Lima, numa carta:

\section{Amigo Nemésio:}

\section{Saudações}

Você, afinal, não quis publicar a crônica que lhe mandei sobre um livro do protestante Basilio Catalá [de] Castro, no que, aliás, está você de acordo com o seu já conhecido ódio à Igreja de Deus. Sem nenhum sentimento de rancor, e sem nenhuma intenção de represália, mas, simplesmente em sinal de respeito à minha Fé, e por coerência comigo mesmo, peço-lhe que mande suspender a remessa de "O Lidador" para mim. No mundo há outras gazetas, meu amigo, e não será o silêncio da sua que há de abalar a solidez da universal e a Igreja fundada pelo próprio Jesus [...]?

O discurso conservador de Eulálio Motta acerca da religião revelava, naturalmente, a sua ligação com a Ação Católica e com os ex-integralistas. A prudência de Nemésio Lima é compreensiva, uma vez que não seria aconselhável para nenhum pequeno jornal do interior, no início da década de I940, publicar

9 MOTTA, Eulálio de Miranda. Caderno Farmácia São José, f. I3vº, EA2.3.CVI.03.00I, 02.Io.I942. 
textos que revelassem certa intolerância religiosa, ainda mais de autoria de um ex-integralista polêmico como Eulálio Motta.

Sem acesso aos jornais, ele passou a publicar seus textos em forma de panfletos. Eulálio Motta assumia o custo da impressão e toda a responsabilidade da publicação, já que todos os textos eram assinados com o intuito de demonstrar uma atitude política destemida. Assim, ele se tornou panfletário por sua própria conta, responsabilizando-se pela escrita, impressão e distribuição dos seus panfletos. Desse modo, não haveria censura direta de terceiros a seus textos, pois as tipografias ofereciam serviços de impressão a qualquer cidadão que pagasse pelo trabalho, sem se responsabilizarem pelo conteúdo dos textos. Em nenhum dos panfletos preservados por Eulálio Motta em seu acervo existe qualquer referência à casa tipográfica que os imprimiu (logomarca, marca d'água etc.). Tudo o que se sabe sobre as tipografias que imprimiam os panfletos decorre das anotações nos cadernos, cartas e documentos do acervo.

Numa carta dirigida ao padre dom Francisco Leite, Eulálio Motta, mais uma vez, esboçou o seu projeto panfletário e apresentou importantes aspectos da produção, circulação, usos e até mesmo arquivamento dos seus panfletos:

Reverendíssimo Padre D. Francisco Leite:

Louvado seja N. S. Jesus Cristo.

[...] Sobre a publicação da “carta aberta”, permita V. Reverendíssima que eu opine, a fim de lembrar que, para a finalidade em vista - esclarecer católicos pouco instruídos, a fim de evitar que venham a ser vítima dos erros protestantes, são, talvez, de mais utilidade, a distribuição dos prospectos que estou remetendo junto a esta. Aliás, imprimi, publiquei e distribui 500 exemplares de "A carta aberta”. No momento só me restou um, que conservei para o meu arquivo, motivo por que deixo de remetê-lo. Se, entretanto, apesar desta minha opinião, o sr. achar conveniente a publicação da "Carta aberta", poderei mandar este exemplar do meu arquivo, uma vez que, entretanto, a "carta”, ao ser enviada ao prelo, sofreu modificações da cópia que José Almeida entregou a V. Reverendíssima. Estou escrevendo uma série de crônicas da natureza destas que ora envio, a fim de publicar em volume, oportunamente, para distribuição nos ambientes onde possa[m] ser úteis. Julgo este trabalho um dever de caridade e é, também, um compromisso que assumi com o meu confessor, no dia da minha conversão, que foi a Io de outubro de $194 \mathrm{O}^{\mathrm{IO}}$.

Segundo Marc Angenot ${ }^{\text {II }}$ a carta aberta é um dos gêneros preferidos do panfletário, porque ele converte o público leitor num segundo destinatário e a polêmica se instaura de imediato, pois o que seria privado se torna público, violando o direito de privacidade que assiste a todos os indivíduos. A "carta aberta" a que

Io Ibidem, f. $6 \mathrm{Ir}^{\circ}$ e f.6Iv ${ }^{\circ}$. Foi mantida a grafia original.

II ANGENOT, Marc, op. cit. 
Eulálio Motta se refere é um panfleto que ele publicou, revelando um debate religioso, entre ele e Eudaldo Lima, que teve consequências desastrosas para a família Motta.

A carta dirigida ao padre dom Francisco Leite é bastante elucidativa, porque expõe as intenções de Eulálio Motta ao publicar o polêmico panfleto que, segundo ele, tinha a função de orientar os católicos, cumprindo assim uma missão pedagógica, evangelizadora e redentora, peculiar aos panfletários. Na carta, Eulálio Motta declara que estava escrevendo uma série de outros panfletos para publicação posterior, mostrando a intensa produtividade do panfletário que não cessava de escrever, como fica evidenciado em seus cadernos e em declarações nos impressos.

Ele ainda menciona a existência de um portador encarregado de entregar o seu panfleto ao padre Francisco Leite. O portador é uma figura importante na história desses panfletos, porque, além de se encarregar de entregar o texto já impresso a pessoas em outras cidades, como foi o caso citado na carta, ele também tinha a função de levar os originais às tipografias, onde os textos eram impressos, e trazê-los de volta a Mundo Novo. Quando o portador esquecia ou extraviava os originais, todo o empreendimento era prejudicado.

Algumas vezes, Eulálio Motta explicou aos leitores os motivos do atraso de algumas publicações ou justificou algum assunto importante que não fora coberto pelos seus panfletos por conta de falha entre o envio dos originais e o recebimento dos impressos. Seguem alguns exemplos das notas de esclarecimento sobre atrasos nas publicações:

Este comentário foi escrito em I7-Io-66, para ser publicado antes da eleição. Aconteceu que o portador que o levou para a oficina de impressão esqueceu de entregar ${ }^{\mathrm{I2}}$.

ESCLARECIMENTO: As linhas que se seguem são apenas o final de um artigo pondo em foco alguns dos numerosos fatos reveladores de um mar de lama local. Artigo que faz parte de uma série. Foi escrito ao findar o primeiro mês de administração de Ederval Neri. Vem a público com tão grande atraso porque, mais uma vez, a correspondência enviada à oficina não chegou ao seu destino ${ }^{\text {I3 }}$.

Os esclarecimentos, destacados acima, podem ser apenas uma estratégia retórica para justificar o atraso na publicação do panfleto, porque a ação do panfletário deveria ser rápida e essa rapidez qualificava o seu discurso. Estratégia retórica ou não, esses dados são relevantes para a história dos panfletos.

$\mathrm{Na}$ carta dirigida ao padre dom Francisco Leite, Eulálio Motta menciona as alterações por que seus textos passavam entre o prelo e a impressão, revelando o modo como se constituía a produção dos panfletos - em alguns casos, os erros eram tantos que ele não distribuía o impresso ${ }^{\mathrm{TI}}$.

Ainda nessa mesma missiva, Eulálio Motta se refere à quantidade de exemplares

I2 MOTTA, Eulálio de Miranda. Viva a esperança!, I966, op. cit.

I3 Idem. Fatos em foco. Panfleto. Mundo Novo, 20 de maio de I967.

I4 Idem. Segunda edição. Panfleto. Mundo Novo, 5 de dezembro de I972. 
que mandara imprimir da Carta aberta ${ }^{15}$ : “[...] imprimi e distribuí 500 exemplares de 'A carta aberta"' ${ }^{6}$. A quantidade de exemplares dos panfletos também foi mencionada num rascunho de carta ao diretor da editora Mensageiro da Fé de Salvador.

Snr. Diretor de “Mensageiro da Fé.”

Saudações.

Sirvo-me desta para o seguinte:

O Snr. Martin Lutero mantém, nesta zona, alguns postos de envenenamentos, contra os quais a gente deve estar alerta. [...] Aqui se tem feito muito pouco contra a ação perniciosa dos tais pastores. [...] Fizemos há tempos uma crônica perguntando quem pregava o Cristianismo antes de Lutero etc., e eles não gostaram da pergunta. Agora, para tirarem o cavalo da chuva estão resmungando que a Igreja Católica também não vem dos tempos apostólicos etc. Daí a crônica que estou remetendo junto a esta para o seguinte: - Imprimir um milhar e mandar-me, com a conta, 300 folhetos, podendo entregar os 700 restantes a D. Francisco, Mosteiro de São Bento. Sendo possível, publicar no "Mensageiro"

No caderno Anotações (f. $30 \mathrm{r}^{\circ}$ ) consta que foi solicitada a Bráulio Franco a impressão de mil folhetos com seis trovas. Com base nesses dados, pode-se concluir que a tiragem dos panfletos era variável, ou seja, não se imprimia sempre a mesma quantidade de exemplares, variando entre 500 e I.000 panfletos.

No rascunho de uma carta de I95I, dirigida a Ivo, Eulálio Motta sintetizou a sua estratégia panfletária, revelando os motivos da utilização de panfletos em detrimento de outros impressos para se comunicar com o povo. Segue trecho da referida carta:

Considero errada a ideia de gazeta doutrinária. Seria de muito mais proveito: publicações mensais de folhetins bem escolhidos, com artigos tipo destes que você me mandou, e publicações, de quando, pelo menos bimensalmente, de artigos do chefe na imprensa burguesa. Para o povo precisamos de coisas práticas, imediatas, como ataques ao regime de partidos e explicação de como funciona, na prática, um regime corporativista. Simultaneamente: ação religiosa intensa, com doutrina e prática. [...] Embora não creia na eficiência de gazeta doutrinária, fique certo de que não lhe faltará o meu apoio material, na medida das minhas possibilidades [... ${ }^{\mathrm{T}}$.

Eulálio Motta chama a atenção para a necessidade de se manter uma regularidade de publicações com linguagem objetiva, capaz de "instruir" o povo (os verdadeiros interlocutores de seus panfletos). Segundo ele, é para o povo que se publicam

\footnotetext{
I5 Carta aberta foi um panfleto que Eulálio Motta publicou, do qual não foi preservado nenhum exemplar.

I6 MOTTA, Eulálio de Miranda. Caderno Farmácia São José EA2.3.CVI.03.00I, I942, f. 74rº.

I7 Idem. Caderno Farmácia São José. EA2.3.CVI.03.00I, I942, f. 74rº.

I8 Idem. Caderno sem capa 2. EA2.8.CVI.08.00I, II.I2.I95I, f. 50v e $5 \mathrm{Ir}^{\circ}$. Manteve-se a estrutura textual original.
} 
panfletos, evidenciando claramente uma oposição entre imprensa burguesa, no caso as gazetas, e o panfleto feito para as massas. Os panfletos geralmente eram distribuídos gratuitamente e por esse motivo tinham um alcance muito maior do que as gazetas. Além disso, por conta de suas dimensões, o seu custo era menor.

Os panfletos de Eulálio Motta correspondem a crônicas do cotidiano, relacionadas a temas pertinentes ao momento, às inquietações políticas e à divulgação de sua poesia. Levando-se em consideração o conteúdo, as demandas do cotidiano e as circunstâncias pessoais do autor, podem-se agrupar os 57 panfletos preservados no acervo de Eulálio Motta em seis categorias que se relacionam entre si:

I) o debate religioso com o propósito de defender o catolicismo como modelo de religião, através de um discurso pautado nas orientações teóricas do integralismo e da Ação Católica; além da necessidade de se criar uma imagem de bom católico para expurgar o antigo estigma de ateu;

2) a polêmica emancipação do município de Piritiba. Nos documentos do acervo, consta que Eulálio Motta escreveu mais de 60 panfletos sobre esse tema, embora tenha sido preservado apenas um impresso;

3) a política partidária e o envolvimento nas eleições municipais e estaduais a partir de uma visão conservadora ligada aos princípios do integralismo e da defesa de interesses pessoais. Eulálio Motta utilizou os panfletos como meio de persuasão e instrumento de campanha eleitoral;

4) a defesa da ditadura militar de I964. Eulálio Motta assumiu um discurso totalitário de exaltação ao regime, representando a voz dos generais em Mundo Novo e região; 5) Eulálio Motta escreveu diversas crônicas sobre o cotidiano do município de Mundo Novo, cobrando providências para solucionar questões pontuais da cidade, criticando determinados acontecimentos, sem assumir algum partido, ou, simplesmente, narrando algum episódio corriqueiro;

6) a divulgação e autopromoção de seus poemas de temática amorosa.

Muitas vezes, para abordar determinado tema, Eulálio Motta tomava como exemplo uma situação do cotidiano para depois chegar ao ponto desejado. No caso do panfleto A pergunta de Rafael I9, por exemplo, ele começa descrevendo uma cena do cotidiano da fazenda, abordando a situação da população rural do Nordeste brasileiro, para depois chegar ao tema da ditadura militar, elogiando a ação dos generais que, segundo ele, conseguiam aposentar os trabalhadores rurais. No panfleto Alto Bonito ${ }^{20}$, o autor narra uma visita ao povoado onde nasceu para vê-lo iluminado pelas lâmpadas elétricas, mas aproveita para criticar a falta de atenção dos órgãos públicos, que não davam a devida manutenção, substituindo as lâmpadas queimadas. Inicialmente, o que parece ter motivado a escrita do panfleto não fora a cobrança de providências, mas o registro de acontecimentos do cotidiano, rememorando momentos de sua infância.

Assim, fica evidente que num mesmo panfleto pode ser abordado mais de um assunto. A tipologia textual não interfere na temática abordada. Um poema pode ser

I9 Idem. A pergunta de Rafael. Panfleto. Mundo Novo, outubro de I972.

20 Idem. Alto Bonito.... Panfleto. Mundo Novo, I4 de julho de I978. 
utilizado para fazer determinadas reivindicações ou exaltar uma figura pública com o propósito de fazer propaganda política, visando aos pleitos eleitorais.

O principal tema tratado nos panfletos de Eulálio Motta é a política partidária, reveladora de seu envolvimento em diversos acontecimentos da história do município de Mundo Novo. Ele manteve uma boa relação com as autoridades políticas de Mundo Novo até as eleições de I962, quando o importante líder da política local, ex-prefeito e candidato novamente à prefeitura da cidade, Osvaldo Paulino Vitória, resolveu apoiar Waldir Pires para governador do estado. Foi nessa ocasião que o panfletário partiu para o combate no cenário político do município, exercendo grande influência nas eleições municipais.

No primeiro mandato como prefeito de Mundo Novo, Osvaldo Vitória (I954-I958) apoiou Otávio Mangabeira, derrotado por Antônio Balbino, que não favoreceu Mundo Novo durante a sua administração. Além disso, Mangabeira apoiou a emancipação de Piritiba, tornando-se inimigo político de Eulálio Motta. No primeiro mandato de Osvaldo Vitória, Eulálio Motta esteve ao seu lado, participando efetivamente da administração do município, redigindo discursos para o prefeito e o representando no caso da emancipação de Piritiba. Em I962, Waldir Pires era o candidato de Antônio Balbino e pertencia ao Partido Comunista do Brasil, por isso o apoio de Osvaldo Vitória a Waldir Pires incomodou tanto Eulálio Motta. Num panfleto de 25 de julho de I962, Eulálio Motta adverte os políticos de Mundo Novo quanto ao apoio a Waldir Pires:

[...] Waldir Pires - o homem que vendeu I50 quilômetros de território dos distritos de Alto Bonito e Sede de Mundo Novo, por votos piritibanos. Candidato de Balbino [...]. É de se esperar que o pessedista Osvaldo Vitória e o pessedista Dilton Jacobina saibam colocar o sentimento de honra mundonovense, de brios de nossa gente, acima de quaisquer [sic] apoio dedicado, não fazendo esforços em favor do inescrupuloso demagogo que invadiu nossos distritos vendendo pedaços de nosso chão por votos piritibanos $^{21}$.

A partir de I964, a ação panfletária de Eulálio Motta intensificou-se, tornando-se agressiva, combatendo de forma direta seus inimigos políticos no âmbito municipal. Isso se justifica pelo fato de ter adotado um discurso em favor do regime militar. As ofensas, os xingamentos, o tom denunciativo e a crítica mordaz eram feitos em nome da ordem, do progresso e da manutenção da "Revolução de I964". Assim, Eulálio Motta desenvolveu uma estratégia retórica que permitia ataques deliberados aos prefeitos de Mundo Novo e aos seus desafetos políticos, num momento de intensa censura. Segundo ele, sua missão era preservar os princípios filosóficos da "revolução". No panfleto No décimo aniversário, o autor denunciou a politicagem em Mundo Novo e lamentou não ver efetivados os propósitos do regime na sua cidade natal: “[...] quando vejo os municípios entregues à mesma politicagem sórdida dos anos anteriores à Revolução, fico sem graça, fico triste, fico sem esperança de que

2I Idem. Dois extremos. Panfleto. Mundo Novo, 25 de julho de I962. 
estas misérias municipais acabem sendo focalizadas pela Revolução, para o seu extermínio definitivo!"22.

Eulálio Motta publicou panfletos polêmicos envolvendo questões políticas até I986. A partir de então, utilizou os impressos avulsos para divulgar sua poesia, fazer propaganda de livros que não chegaram a ser publicados e destacar a sua condição de poeta. No panfleto Opiniões ${ }^{23}$, por exemplo, Eulálio Motta apresentou uma lista com a opinião de diversas pessoas a respeito da publicação da segunda edição de Canções de meu caminho. Esse panfleto corresponde a uma tentativa clara de exaltar as qualidades literárias e construir uma imagem de bom poeta, admirado por muitos "intelectuais". Nos panfletos com poemas, Eulálio Motta inseriu a opinião de algumas pessoas e, com isso, propôs a leitura de um texto já avalizado por terceiros

A inserção desse tipo de notas introdutórias aparece em diversos panfletos, constituindo-se em importantes peritextos que, segundo Genette ${ }^{24}$, são elementos paratextuais inseridos no suporte que transmite o texto, tais como notas, prefácios etc. As notas introdutórias dos panfletos de Eulálio Motta funcionam como prefácios, destacando a opinião de alguém ou informando ao leitor a origem do texto e as circunstâncias de sua escrita:

[Exemplo I]

Este comentário foi escrito em I7-Io-66, para ser publicado antes da eleição. Aconteceu que o portador que o levou para a oficina de impressão esqueceu de entregar. EDERVAL NERI era apenas um candidato com "muita probabilidade de ser eleito Prefeito de Mundo Novo" 25.

[Exemplo 2]

ESCLARECIMENTO: As linhas que se seguem são apenas o final de um artigo pondo em foco alguns dos numerosos fatos reveladores de um mar de lama local. Artigo que faz parte de uma série. Foi escrito ao findar o primeiro mês de administração de Ederval Neri. Vem a público com tão grande atraso porque, mais uma vez, a correspondência enviada à oficina não chegou ao seu destino. 28-7-967 ${ }^{26}$.

[Exemplo 3]

22 Idem. No décimo aniversário. Panfleto. Mundo Novo, 2 de abril de I974.

23 Nesse panfleto constam opiniões de intelectuais como, por exemplo, Jorge Amado, Ruben Nogueira, Gertrudres Marx.

24 GENETTE, Gérard. Paratextos editoriais. Tradução de Álvaro Faleiro. São Paulo: Ateliê, 2009, p. I2.

25 MOTTA, Eulálio de Miranda. Viva a esperança!, I966, op. cit.

26 Idem. Fatos em foco, I967, op. cit. 
Crônicas engavetadas. Tenho várias. Aqui está uma datada de abril de 1965. Como o assunto se tornou oportuníssimo resolvi publicá-loº

\section{[Exemplo 4]}

Da Crônica “Fora do Mapa”. Porque a primeira saiu com erros de impressão incorrigíveis: omissões de palavras e frases, alterando o sentido do conjunto ${ }^{28}$.

Essas pequenas notas-prefácios cumprem uma importante função no panfleto e se relacionam aos temas abordados. A partir das datas contidas nessas notas introdutórias, foi possível mensurar o tempo decorrido entre a escrita dos textos e a sua publicação. No exemplo 2, consta que o texto do panfleto foi escrito em 20 de maio de I967, mas, de acordo com a nota-prefácio, somente foi publicado em 28 de julho de I967.

Além das notas introdutórias, existem, nos panfletos, outros peritextos - são notas de fim de página, contendo referências bibliográficas, indicação da fonte de onde o texto foi copiado (no caso os cadernos do autor) e ainda os post-scripta que funcionam como posfácios.

NOTA: - As citações foram colhidas no livro "O que é o espiritismo", de Negromonte. Tomo a liberdade de recomendar este livro a todos que se interessem pelo assunto ${ }^{29}$.

P. S. -É bom esclarecer “a quem interessar possa” que: - voltando à ação de "escriba da roça”, não tenho nenhuma intenção de me meter na política local. Porque a mim e aos meus não interessam honrarias de Sucupira ${ }^{30}$.

Os panfletos mantêm uma intrínseca relação com o autor e seus projetos intelectuais, com a cultura escrita e as circunstâncias sócio-históricas do lugar e do tempo em que esses textos circularam. Portanto, para compreendê-los, faz-se necessário conhecer o contexto e o modo como eles foram escritos.

Quando Eulálio Motta começou a publicar seus panfletos, não havia tipografia em Mundo Novo, sendo necessário utilizar os serviços oferecidos pelas oficinas gráficas de Morro do Chapéu, Feira de Santana, Jacobina, Rui Barbosa e Salvador, mas a tipografia do jornal O Serrinhense, de Bráulio Franco, em Serrinha, sempre foi sua preferida. Numa carta ao proprietário do jornal Folha do Norte, de Feira de Santana, o jornalista Zadir Marques Porto, Eulálio Motta declara essa preferência:

Há muito que desisti de publicações desiludido de impressores e revisores que erram demais. Imagine que em S. Paulo, numa coletânea intitulada "poesias consagradas", foi incluído um soneto meu - “Aniversário”, faltando um verso todo do primeiro quarteto [...].

27 Idem. A pergunta de Rafael, I972, op. cit.

28 Idem. Segunda edição, I972, op. cit.

29 Idem. O que importa. Panfleto. Mundo Novo, novembro de I949.

30 Idem. No décimo aniversário, I974, op. cit. 
Até minhas publicações em folhetos me deram muitas dores de cabeça. Felizmente descobri "O Serrinhense" onde o admirável Bráulio Franco faz a coisa de modo a "ninguém botar defeito". [...] Junto a esta alguns exemplares saído[s] das oficinas de "O Serrinhense" que comprova[m] o que afirmo ${ }^{31}$.

Nessa carta, fica claro que os tipógrafos cometiam muitos erros nos textos de Eulálio Motta. Devido a esses erros, ele precisou reeditar um deles, como fica evidente numa nota introdutória no panfleto Segunda edição: “Da crônica 'Fora do Mapa'. Porque a primeira saiu com erros de impressão incorrigíveis: omissões de palavras e frases, alterando o sentido do conjunto" ${ }^{32}$. Em muitos casos, o autor fez emendas nos textos utilizando caneta, antes da sua distribuição.

Os panfletos de Eulálio Motta eram escritos para atenderem a questões pontuais de um momento específico e, por conta disso, o tempo que levava para o envio do original para ser impresso em outras cidades, dependendo de um portador ou do serviço dos correios, muitas vezes prejudicava os planos do panfletário. Algumas vezes, ele registrou esses atrasos, como se observa em notas nos panfletos Viva a esperança! e Fatos em foco, já citados.

Além da morosidade entre o envio do original e o retorno do texto impresso, era comum o portador esquecer-se de entregar o original na tipografia ou extraviá-lo. Por isso, quando os panfletos precisavam ir para a rua rapidamente, Eulálio Motta lançava mão de mimeógrafos para imprimi-los. Esse processo de impressão era o mais rápido de que se dispunha, já que não era necessário levar os originais a outra cidade e aguardar o seu retorno.

Pouco lembrados na história da cultura dos impressos, os textos reproduzidos por meio dos mimeógrafos foram responsáveis pela formação de leitores e pela difusão de diversos tipos de textos. Eles, talvez, ainda sejam utilizados por associações, igrejas, sindicatos e escolas, porque se constituem num meio barato e rápido de imprimir textos e difundir ideias. A impressão dos panfletos em mimeógrafos foi uma alternativa para publicar alguns textos de modo mais rápido, mas isso não se constituiu numa regra. Eulálio Motta preferia imprimi-los em oficinas tipográficas.

As encomendas de impressão feitas às tipografias do sertão baiano variavam de preço, dependendo do número de exemplares, da qualidade do papel e, principalmente, do design gráfico. Segundo os anúncios nos periódicos, os detalhes da impressão deveriam ser acertados previamente mediante pagamento adiantado e incluíam a definição da quantidade de exemplares, tipo de papel, cor da tinta e design.

No caso de Eulálio Motta, por ser colaborador dos jornais e amigo dos donos das tipografias, o serviço poderia ser pago posteriormente, como se pode notar no rascunho da carta enviada ao proprietário do jornal Gazeta do Povo, de Feira de Santana:

3I Idem. Caderno Diário de um João Ninguém II. EA2.5.CVI.05.00I, f.4r $\mathrm{r}^{\circ}$ e vo , O4.oI.I977.

32 Idem. Segunda edição, I972, op. cit. 
Zo e B.

Acabo de receber um bilhete de Arnaldo comunicando que chegaram os folhetos que não mandei imprimir. E agora? Não me conformo em pagar uma encomenda que não fiz e tenho deveres de gratidão por muitas gentilezas velhas e novas que tenho recebido de você. Aliás, você não mandou imprimir, apenas pediu a informação de preço, como propôs e o nosso Galeão precipitou-se. E agora? A publicação só seria autorizada depois do livro seguir para o prelo. E isto já não seria como a dessa redação que modifiquei quase radicalmente depois de ter-lhe remetido a cópia ${ }^{33}$.

As características da arte gráfica eram classificadas em três diferentes categorias: simples, sofisticada e especial. A tipografia do jornal O Serrinhense, por exemplo, cobrava $20 \%$ a mais no valor do serviço, caso o cliente exigisse uma arte gráfica sofisticada, e cerca de $40 \%$ a mais por um design especial que demandasse a impressão de imagens ${ }^{34}$.

Os impressos considerados como simples não exigiam trabalhos gráficos complexos que correspondessem a projetos elaborados em função da arte tipográfica. Nesses casos, não havia muita variação de tamanho e forma dos tipos de letras, as linhas eram longas e contínuas, o espacejamento não obedecia a critérios estéticos recomendados nos manuais de prática tipográfica. Por sua vez, os impressos considerados como sofisticados correspondiam a projetos gráficos bem estruturados do ponto de vista da diagramação (com divisão em colunas, linhas curtas, espacejamento adequado ao tipo e tamanho de fontes, ocupação e distribuição da mancha escrita na folha de forma equilibrada), da utilização de tipos e fontes adequados a critérios estéticos que valorizavam o conteúdo do texto. A arte gráfica especial acumulava as mesmas características da sofisticada, além de conter imagens e sinais especiais que demandavam habilidades e materiais específicos.

As oficinas onde Eulálio Motta imprimiu seus panfletos dispunham de imprensa manual de tipos móveis. A única exceção era a tipografia do jornal Gazeta do Povo, de Feira de Santana, que adquiriu, em I960, uma linotipo.

[...] Minhas felicitações pelo progresso de nossa "Gazeta do Povo" com aquisição da linotipo. Ela não nasceu com cara de semanário: tudo indica que será o primeiro diário da "Princesa do Sertão". A linotipo é um passo no caminho do destino de gazeta que não nasceu com cara de semanário. [...] Estou trabalhando no "Bofetada”. Pretendo ir aí, logo que o tenha datilografado, para um bate-papo a respeito da $I^{\mathrm{a}}$ edição. Talvez acertemos algo a respeito!

Na minha próxima ida aí, quando terei o prazer de conhecê-lo pessoalmente, acertaremos as contas do folhetos impressos e de outros que pretendo imprimir

33 Idem. Caderno monitor, EA2.9.CVI.09.00I, f. 63v ${ }^{\circ}$, s.d.

34 O SERRINHENSE. Serrinha, 20 de novembro de I949, p. 3. 
proximamente. Com um grande abraço muito cordial, o até breve do patrício e sincero admirador ${ }^{35}$.

Apesar de ter adquirido uma linotipo, a oficina da Gazeta do Povo manteve em funcionamento a sua prensa manual, para imprimir textos de pouca tiragem. A vantagem da linotipo era a velocidade com que se preparava o texto para a reprodução e a quantidade de cópias que se conseguia. Na linotipo, em três horas um jornal estava pronto para circulação. As antigas prensas manuais continuaram sendo usadas para impressão de cartões, folhetos e panfletos de até mil cópias.

Segundo Bringhurst ${ }^{36}$, a prensa de tipos móveis tem características que as chapas de chumbo da linotipia, os fotolitos da offset e a impressão digital não conseguem reproduzir. Trata-se das marcas deixadas na superfície do papel pela pressão das matrizes de tipos individuais, montados um a um.

Os panfletos de Eulálio Motta não apresentam layouts muito sofisticados, como inserção de imagens ou aplicação de técnicas tipográficas especiais, por conta de sua natureza efêmera e dos custos de impressão. Esses panfletos não eram vendidos, o próprio autor assumia todo o custo, distribuindo-os gratuitamente. O objetivo de Eulálio Motta era alcançar o maior número possível de leitores, por isso, ele preferia investir na quantidade de exemplares. Embora a qualidade do papel e o design gráfico ficassem em segundo plano, em grande parte desses panfletos foram empregados recursos tipográficos simples que valorizaram o texto, tais como diversos tipos e tamanhos de fontes, bordas decorativas, diferentes cores de tinta, papéis com dimensões, cores, gramatura e lisura variados.

Os panfletos foram impressos em papel de imprensa, comercializados em folhas lisas para prensas planas e cortados nas dimensões adequadas ao tamanho do texto. O menor panfleto mede $160 \mathrm{~mm} \times 233 \mathrm{~mm}$ (Natal37), e o maior, $220 \mathrm{~mm} \times 330 \mathrm{~mm}$ (Cegos... ${ }^{38}$ ). O papel de imprensa, também conhecido como papel-jornal, varia de gramatura, lisura e cor. Quando a impressão é feita em apenas um lado, como no caso dos panfletos, é comum a utilização do papel mais fino, de baixa gramatura, por ser mais barato. Embora isso não tenha sido uma regra no caso dos panfletos de Eulálio Motta. A vantagem do papel de baixa gramatura é que, geralmente, ele é mais liso (baixa porosidade) e tem pouca acidez, demorando mais tempo para ficar amarelado e se deteriorar.

As diferentes escolhas do tipo de papel expressam um valor simbólico que compõe a sócio-história do texto e envolvem questões estéticas, econômicas, o perfil do público leitor e o lugar onde o texto circula. No conjunto dos panfletos de Eulálio Motta, apenas Alegria e gratidão $0^{39}$, publicado em I5 de março de I972, por

35 MOTTA, Eulálio de Miranda. Caderno monitor, EA2.9.CVI.09.00I. f. $69 \mathrm{r}^{\circ}$ e v ${ }^{\circ}$, s.d.

36 BRINGHURST, Robert. Elementos do estilo tipográfico - versão 3.o. Tradução de André Stolarcki. São Paulo:

Casac Naify, 2005.

37 MOTTA, Eulálio de Miranda. Natal. Panfleto. Mundo Novo, I949.

38 Idem. Cegos.... Panfleto. Mundo Novo, I960.

39 Idem. Alegria e gratidão. Mundo Novo, I5 de março de I972. 
ocasião de uma visita do governador Antônio Carlos Magalhães a Mundo Novo, foi impresso num papel especial de alta gramatura, de superfície lisa e em cor azul. A ocasião exigia um tipo especial de papel, afinal de contas, o próprio governador e sua comitiva receberiam um exemplar em mãos. No texto, Eulálio Motta elogia o político e lista os benefícios que o município de Mundo Novo recebera e pretendia receber durante a administração de Antônio Carlos Magalhães.

Segundo Paulo Heitlinger ${ }^{40}$, normalmente se observa o exercício da arte tipográfica e altos investimentos em papéis e tintas especiais em grandes obras, livros memoráveis de autores consagrados e ricos periódicos que são tesouros do design gráfico. Os pasquins, folhas volantes, panfletos e folhetos de cordel são impressos simples e baratos, em papel e "[...] tipos de metal de péssima qualidade, com o refugo tipográfico, por assim dizer"4. Esses tipos de impressos, comumente, não correspondem a trabalhos tipográficos laboriosos, pelas circunstâncias em que são produzidos, pelo custo da elaboração de um design sofisticado, pela rapidez com que são impressos e, sobretudo, porque eles não são feitos para durar. Além disso, eles não são produzidos para serem lidos devagar nos confortáveis gabinetes de leitura ou em bibliotecas e, na maioria das vezes, estão associados a práticas tipográficas sediciosas, clandestinas e à margem dos meios oficiais de publicação.

No caso da impressão dos panfletos de Eulálio Motta, não se pode dizer que em todos eles foram utilizados tipos de péssima qualidade ou o "refugo tipográfico", como sugere Heitlinger ${ }^{42}$ ao se referir a esse tipo de impressos, porque, em grande parte desses panfletos foram utilizadas fontes de designs modernos (serifadas e não serifadas, pesadas e leves, arredondadas, sinuosas, sérias, descontraídas, elegantes, imponentes, manuscritas, clássicas, modernas, fantasiosas etc.). Alguns dos panfletos de Eulálio Motta correspondem a trabalhos tipográficos criteriosos, como se pode observar no exemplo I da Figura I, mas existem também aqueles compostos sem a acuidade da arte tipográfica, como no exemplo 2.

40 HEITLINGER, Paulo. 500 anos de más leituras. Caderno de Tipografia e Design, p. I85-200, n. I6, maio, 2010.

4 I Ibidem, p. 2.

42 Ibidem. 


\section{Dois Extremos}

\section{UM OTIMO E 0 OUTRO PÉSSIMO}

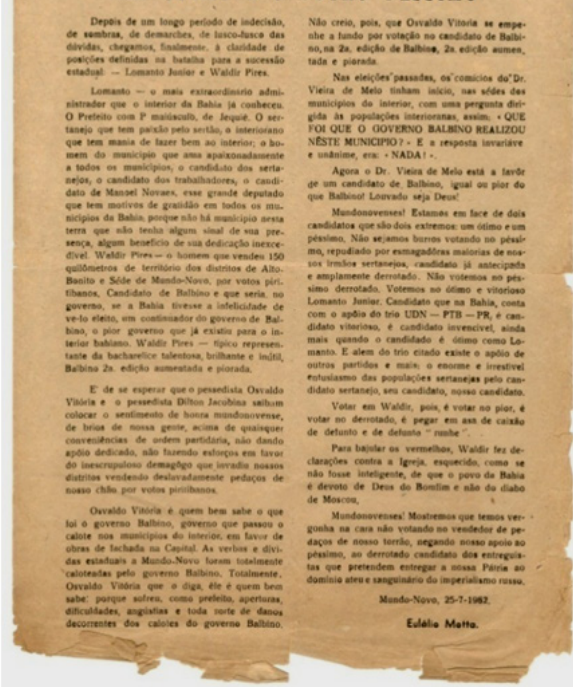

Exemplo 1

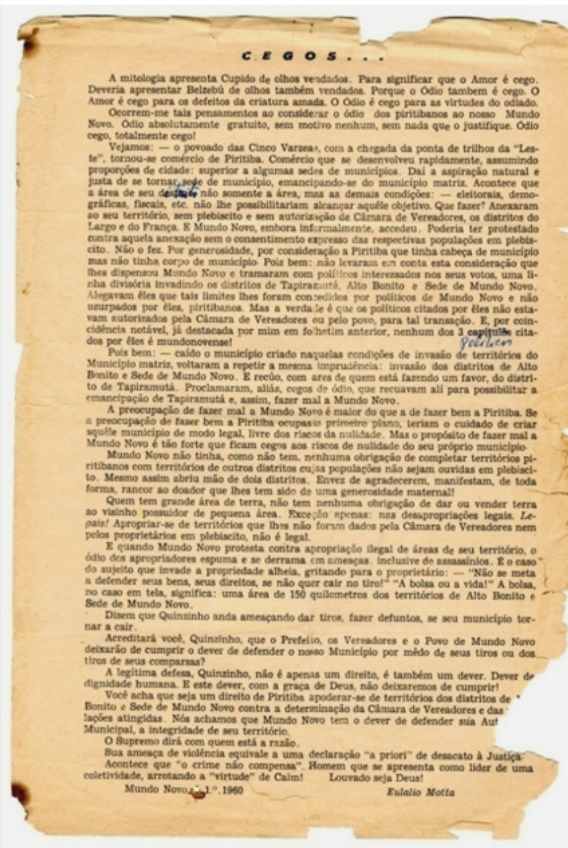

Exemplo 2

Figura I - Diferentes layouts dos panfletos. Fonte: Panfletos Dois extremos e Cegos...

Como já dito, o panfleto é um impresso feito para ser lido na rua, nas filas, em espaços públicos onde há muito movimento, por isso, o olho do leitor deixa o texto para se fixar no movimento ao seu redor e retorna ao texto muitas vezes. Quando a técnica tipográfica empregada não leva em consideração esses detalhes, a leitura pode ser prejudicada. Por isso, o design tipográfico de um panfleto precisa adequar-se às práticas de leitura em que ele está implicado.

Segundo Heitlinger ${ }^{43}$ e Bringhurst ${ }^{44}$, o design de impressos para serem lidos nas ruas enquanto se está andando ou em filas deve observar questões básicas, tais como: a) utilizar linhas curtas com espacejamento confortável entre linhas; b) o espaço entre as palavras deve ser equilibrado; c) as fontes empregadas devem ser visualmente claras; d) os destaques de palavras precisam ser bem marcados.

Alguns desses princípios são observados no exemplo I da Figura I (Dois extremos). O tipógrafo teve o cuidado de ressaltar o título de modo criativo, alternando maiúsculas e minúsculas da fonte helvética, indicada para títulos por ser estreita e não conter serifas, tornando as palavras mais legíveis e visualmente atraentes. O design desse panfleto é bem estruturado desde a distribuição do texto no papel. O título e o subtítulo foram harmonicamente situados no topo da folha, com espacejamento maior entre as letras e alternância de fontes (sem serifa no título e

43 Ibidem.

44 BRINGHURST, Robert, op. cit. 
com serifa no subtítulo). A utilização de colunas e espaços maiores entre os parágrafos proporcionou um layout equilibrado e convidativo para a leitura.

No exemplo 2 (Cegos...), da Figura I, observa-se um layout bastante simples. Em todo o impresso, com exceção do título, utilizou-se apenas um tipo de fonte, a scotch roman, da família das romanas serifadas. Houve variação de tamanho de fonte apenas no título, as linhas são longas, não há espaço especial entre os parágrafos e o espacejamento de entrelinha é pequeno, tornando a leitura cansativa. Nesse panfleto também ocorreram problemas de impressão conhecidos como erros de gralha, provenientes do afrouxamento do tipo na prensa, provocando o desalinhamento da letra, que, do ponto de vista da arte tipográfica, são considerados primários e desqualificam o trabalho do tipógrafo.

Na impressão dos panfletos de Eulálio Motta, observam-se práticas resultantes da imperícia do tipógrafo, que interferem no aspecto gráfico do texto, dentre as quais se destacam: a) utilização sistemática de aspas invertidas; b) lacunas no interior das linhas por conta do espaçamento inadequado entre palavras; c) utilização de fontes diferentes para destacar palavras ou expressões no interior do texto, provocando desarmonia no design gráfico do impresso.

O uso sistemático de aspas invertidas no mesmo impresso pode indicar falta de atenção do tipógrafo, pouca importância dada ao uso de aspas ou limitações de recursos da tipografia. Segundo Freire ${ }^{45}$, muitas vezes, nas pequenas oficinas não era possível utilizar a fonte apropriada para garantir a hegemonia no impresso porque a caixa de tipos estava incompleta ou, dependendo do número de páginas compostas ao mesmo tempo, faltavam letras e sinais, obrigando a fazer substituições que prejudicavam o trabalho.

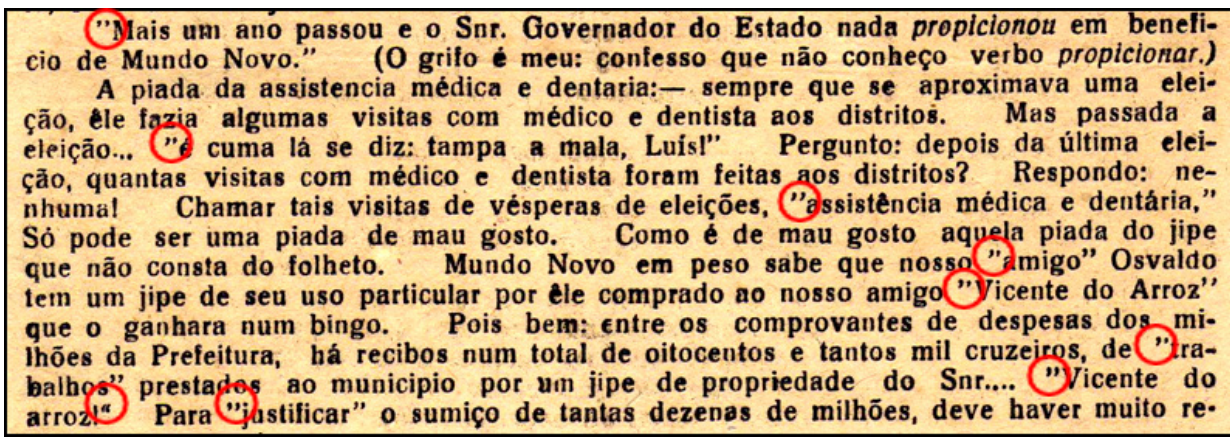

Figura 2 - Exemplo de uso de aspas invertidas. Fonte: panfleto Piadas $4^{4}$

45 FREIRE, Eduardo Nunes. O design no jornal impresso diário. Do tipógrafo ao digital. Revista Galáxia, São

Paulo, n. I8, p. 29I-3Io, de, 2009.

46 MOTTA, Eulálio de Miranda. Piadas. Panfleto. Mundo Novo, Io de março de I967. 
O uso de aspas invertidas ocorreu em cinco panfletos (Viva a esperança!, Quinto aniversário ${ }^{47}$, Piadas, $O$ estopim ${ }^{48}$ e Sexto aniversário $\left.{ }^{49}\right)$, que, pelas características do design gráfico, provavelmente, foram impressos na mesma tipografia. Nesses cinco panfletos também há lacunas muito grandes entre palavras. Para manter o alinhamento da mancha escrita, o tipógrafo alongou alguns espaços entre palavras no contínuo da linha, deixando espaços vazios que prejudicaram o layout.

Segundo Bringhurs $\mathrm{t}^{50}$, sabe-se, desde os primeiros manuais da arte tipográfica impressos no século XIX, que cabe à tipografia a tarefa de tornar os impressos legíveis, atraentes e dentre as suas funções destacam-se: o convite à leitura, a revelação do teor, o significado, a clareza da estrutura e a ordem do texto, sua conexão a outros elementos, a indução a um estado confortável de leitura, tudo isso obedecendo a certa simetria e homogeneidade. Desse modo, ao introduzir um tipo de fonte diferente no corpo de um texto, seja qual for o motivo, deve-se garantir a manutenção da harmonia do design. O ideal seria utilizar fontes com as mesmas características (família, peso, altura etc.) e para os destaques alternar entre maiúsculas e minúsculas, sublinhado, negrito, itálico e tamanho das letras, garantindo a harmonia da mancha ${ }^{5 \mathrm{I}}$.

Em alguns panfletos de Eulálio Motta, os tipógrafos utilizaram fontes diferentes das empregadas no conjunto do texto com o objetivo de dar destaque às palavras e/ou expressões, contrariando o princípio da homogeneidade das fontes, recomendado pelos manuais da arte tipográfica ${ }^{52}$. Nesses casos, os textos foram compostos com fontes serifadas, os destaques grafados com tipos sem serifas e de tamanho maior, como se pode constatar na Figura 3.

\footnotetext{
47 Idem. Quinto aniversário. Panfleto. Mundo Novo, 3I de março de I969.

48 Idem. O estopim. Panfleto. Mundo Novo, 3I de janeiro de I970.

49 Idem. Sexto aniversário. Panfleto. Mundo Novo, 3I de março de I970.

50 BRINGHURST, Robert, op. cit.

5 I MCLEAN, Ruari. Manual de tipografia. Tradução de Catalina Martínez. Madrid: Tursen, I993.

52 BRINGHURST, Robert, op. cit.
} 


\section{Panfleto A pergunta de Rafael ${ }^{a}$}

alegria a quase todos os Rafaeis do Brasil-que a quantia que eles estão re cebendo significa tudo isto. Digo quase todos porque, infelizmente, ainda há Rafaeis velhinhos e tristes para cuios lares está proibida a dávida da previ-

\section{Panfleto Nono aniversário}

do escrevia, magistralmente: "...a complacência com a mediocridade ẹ a hegemonia dos partidos, que tambem não são essenciais à democracia mas que representam a tentação permanente de toda democracia sem vigor es-

\section{Panfleto No ano 12 da revoluçãa $0^{c}$}

curtindo decepções: um Senador da Arena, falando a universitários bahianos sugeriu que os mesmos desfraldassem "a bandeira da liberdade irrestrita" (sic!) Para mim "liberdade irrestrita" é anarquia. Outro senador, tambem da Arena, apelara para a oposição no sentido de fazer uma frente única contra o Ato Institucional

\section{Panfleto Ele vem aí!}

timista com relação à vinda do telefone. Pessimismo não resolve. Os pessimistas não acreditavam que nos viesse Paulo Afonso, que nos viesse o asfalto. $E$ aí estão como estará, brevemente, o telefone.

\section{Panfleto Eleição - Corrupçãa ${ }^{\mathrm{e}}$}

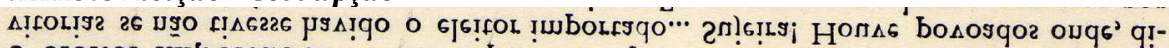

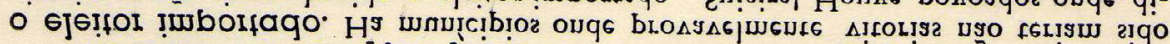

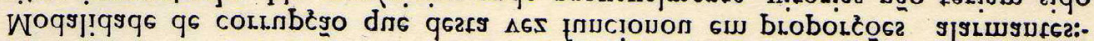
a. MOTTA, Eulálio de Miranda. A pergunta de Rafael, I972, op. cit.
b. Idem. Nono aniversário. Panfleto. Mundo Novo, 3I de março de 1973.
c. Idem. No ano I2 da revolução. Panfleto. Mundo Novo, 5 de abril de 1976.
d. Idem. Ele vem aí!. Panfleto. Mundo Novo, I7 de agosto de 1976.
e. Idem. Eleição - Corrupção. Panfleto. Mundo Novo, 20 de novembro de I976.

Figura 3 - Exemplos de uso de fontes diferentes no corpo do texto. Fonte: panfletos de Eulálio Motta

Esses cinco panfletos, provavelmente, foram impressos na mesma tipografia, e a técnica utilizada para destacar palavras e expressões corresponde a uma característica das práticas do tipógrafo da oficina.

Nas tipografias do sertão baiano, muitas vezes, o próprio dono fazia todo o trabalho de impressão, auxiliado por aprendizes. Bráulio Franco, por exemplo, era quem fazia a composição tipográfica, operava a prensa e fazia a revisão dos impressos em sua oficina. Ele dispunha de dois auxiliares, mas todo o serviço tinha a sua participação e supervisão. O trabalho era orientado pelos manuais de tipografia e pelos catálogos de tipos, no entanto, o responsável pela composição tinha seu 
próprio estilo e encontrava soluções práticas para resolver problemas, fazendo uso dos recursos de que dispunha.

Nem sempre as tipografias tinham condição de remunerar um tipógrafo formado nas poucas escolas profissionalizantes que existiam no Brasil. O tipógrafo, no sertão baiano, era a pessoa habilitada na arte de impressão que aprendia o ofício na prática e, por isso, atuava em todo o processo, não apenas na composição do texto e na elaboração do layout, como geralmente acontecia nas grandes oficinas que hierarquizavam as atividades, numa linha de montagem.

Eulálio Motta datilografava os seus originais e os enviava à tipografia, mas a máquina de escrever tem algumas limitações, o tamanho da fonte é padronizado, não sendo possível utilizar variações de tamanho, dificultando a utilização de subscritos, por exemplo. Portanto, os textos impressos que chegavam aos leitores eram exatamente os mesmos manuscritos ou datiloscritos enviados à oficina tipográfica pelo autor, antes de ganharem

[...] identidade e forma tipográfica próprias. Cada uma das camadas e cada um dos níveis do texto devem ser consistentes, distintos, e ainda assim (em geral) harmônicos em sua forma. Portanto, a primeira tarefa do tipógrafo é ler e entender o texto; a segunda é analisá-lo e mapeá-lo. Só então a interpretação tipográfica pode começar. [...] O tipógrafo está para o texto assim como o diretor teatral está para a peça ou o músico para a partitura53.

O texto impresso é o resultado de um trabalho que envolve tanto o autor quanto os tipógrafos e outros profissionais que atuam no processo de produção do livro, do jornal, do panfleto etc. Segundo Chartier ${ }^{54}$ a criação do texto não envolve apenas a invenção do autor, a sua alma é moldada também pelos tipógrafos, editores ou revisores, que se encarregam da pontuação, da ortografia e do layout do texto.

Ainda para Chartier,

[...] os diferentes atores envolvidos com a publicação dão sentido aos textos que transmitem, imprimem e leem. Os textos não existem fora dos suportes materiais (sejam eles quais forem) de que são os veículos. [...] Contra a abstração dos textos, é preciso lembrar que as formas que permitem sua leitura, sua audição ou sua visão participam profundamente da construção de seus significados ${ }^{55}$.

Por isso, qualquer abordagem que considere o texto em sua sócio-história não pode ignorar as condições de produção, as práticas de reprodução do texto disponíveis na época de sua impressão e os sujeitos envolvidos nesses processos: autores, tipógrafos, revisores, leitores. A esse respeito, Chartier considera que

\footnotetext{
53 BRINGHURST, Robert, op. cit.

54 CHARTIER, Roger. Da história da cultura impressa à história cultural do impresso. Revista Brasileira de

Ciências da Comunicação, São Paulo, v. 28, n. I, p. 8I-I04, 2005, p. 38.

55 Idem. Os desafios da escrita. Tradução de Fulvia M. L. Moretto. São Paulo: Unesp, 2002, p. 62.
} 
[...] os autores não escrevem livros, mas que estes são objetos que requerem numerosas intervenções. Conforme o tempo e o lugar, estas não são idênticas tampouco os papéis se distribuem de igual maneira. Desde meados do século XV, os processos de produção do livro impresso mobilizam os conhecimentos e os procedimentos de todos os que trabalham na oficina tipográfica (editores, revisores, linotipistas, impressos). [...] As técnicas mudam e, com elas, os protagonistas da fabricação do livro, mas permanece o fato de que o texto do autor não pode chegar a seu leitor senão quando as muitas decisões e operações lhe deram forma de livro. Não dá para esquecer isso ao lê-lo ${ }^{56}$.

No caso dos panfletos de Eulálio Motta, é importante compreender o contexto de sua produção, que envolve a materialidade dos textos, os processos de produção das tipografias do sertão baiano e outras técnicas de impressão, bem como as motivações da escrita dos textos e as pessoas encarregadas de fazer a panfletagem, distribuindo-os nas ruas, nas repartições, e os portadores que levavam os originais até as tipografias. Todos esses aspectos são muito relevantes para dar a conhecer a história cultural das práticas de escrita instituídas pelo escritor no interior da Bahia.

\section{SOBRE O AUTOR}

PATRÍCIO NUNES BARREIROS é doutor em Letras

e Linguística pela Universidade Federal da Bahia

e professor do Departamento de Letras e Artes da

Universidade Estadual de Feira de Santana.

E-mail: patricio@uefs.br

\section{REFERÊNCIAS BIBLIOGRÁFICAS}

ANGENOT, Marc. La parole pamphlétaire: typologie des discurs modernes. Paris: Payot, I982.

BARREIROS, Patrício Nunes; BARREIROS, Liliane Lemos Santana. O vocabulário da ditadura militar nos panfletos de Eulálio Motta. Filologia e Linguística Portuguesa, v. I7, p. 385-420, 20I6. Doi: http://dx.doi. org/Io.II606/issn.2I76-94I9.vI7i2p385-420.

BARREIROS, Patrício Nunes. Por uma abordagem da história cultural das práticas de escrita na edição de textos. Alea, Rio de Janeiro , v. I9, n. 2, p. 389-4I4, 20I7. Doi: http://dx.doi.org/Io.I590/ I5I7-IO6x/20I7I923894I4.

. Sonetos de Eulálio Motta. Feira de Santana: UEFS Editora, 2012.

. O Pasquineiro da roça: a hiperedição dos panfletos de Eulálio Motta. Feira de Santana: UEFS Editora, 20I5.

56 Idem. Cultura escrita, literatura e história: conversas de Roger Chartier com Carlos Aguirre Anaya, Jesús Anaya

Rosique, Daniel Goldin e Antônio Saborit. Porto Alegre: Artemed, 200I, p. I9. 
BRINGHURST, Robert. Elementos de estilo tipográfico - versão 3.o. Tradução de André Stolarcki. São Paulo: Casac Naify, 2005.

CHARTIER, Roger. Cultura escrita, literatura e história: conversas de Roger Chartier com Carlos Aguirre Anaya, Jesús Anaya Rosique, Daniel Goldin e Antônio Saborit. Porto Alegre: Artemed, $200 \mathrm{.}$ . Os desafios da escrita. Tradução de Fulvia M. L. Moretto. São Paulo: UNESP, 2002. . Da história da cultura impressa à história cultural do impresso. Revista Brasileira de Ciências da Comunicação, São Paulo, v. 28, n. I, p. 8I-IO4, 2005. . Inscrever e apagar: cultura escrita e literatura. Tradução de Luzmara Curcino Ferreira. São Paulo: UNESP, 2007.

FREIRE, Eduardo Nunes. O design no jornal impresso diário. Do tipógrafo ao digital. Revista Galáxia, São Paulo, n. I8, p. 29I-3Io, de, 2009.

GENETTE, Gerard. Paratextos editoriais. Tradução de Álvaro Faleiro. São Paulo: Ateliê, 2009.

HEITLINGER, Paulo. 500 anos de más leituras. Caderno de Tipografia e Design, p. I85-200, n. I6, maio, 2010. LIMA, Eudaldo. Phco. Eulálio Mota Integralista de convicções. O Lidador, p. I, 3 I jan., I934.

MCLEAN, Ruari. Manual de tipografia. Tradução de Catalina Martínez. Madrid: Tursen, I993.

MOTTA, Eulálio de Miranda. O integralismo vencerá. O Lidador, Jacobina, p. I, 29 de dezembro de 1933. . EA2.3.CVI.03.00I, 02.I0.I94I. Caderno Farmácia São José, f. I3vº. . EA2.3.CVI.03.00I, 02.I0.I94I. Caderno Farmácia São José, f. $6 \mathrm{Ir}^{0}$ e f.6Ivº. . Caderno Farmácia São José, EA2.3.CVI.03.00I, I942, f. 74rº. . O que importa. Panfleto. Mundo Novo, novembro de 1949. . Natal. Panfleto. Mundo Novo, I949. . Caderno sem capa 2. EA2.8.CVI.08.00I, II.I2.I95I, f. 50vº e 5Ir . . Cegos.... Panfleto. Mundo Novo, I960. . Dois extremos. Panfleto. Mundo Novo, 25 de julho de 1962. . Viva a esperança!. Panfleto. Mundo Novo, I7 de outubro de I966. . Piadas. Panfleto. Mundo Novo, Io de março de I967.

. Podridão!!. Panfleto. Mundo Novo, 22 abril, I967. . Fatos em foco. Panfleto. Mundo Novo, 20 de maio de 1967. . Quinto aniversário. Panfleto. Mundo Novo, 3I de março de I969. . O estopim. Panfleto. Mundo Novo, 3I de janeiro de I970. . Sexto aniversário. Panfleto. Mundo Novo, 3I de março de I970. . Alegria e gratidão. Mundo Novo, I5 de março de I972. . A pergunta de Rafael. Panfleto. Mundo Novo, outubro de I972. . Segunda edição. Panfleto. Mundo Novo, 5 de dezembro I972. . Nono aniversário. Panfleto. Mundo Novo, 3I de março de I973. . No décimo aniversário. Panfleto. Mundo Novo, 2 de abril de I974. . No ano I2 da revolução. Panfleto. Mundo Novo, 5 de abril de I976. . Ele vem aí!. Panfleto. Mundo Novo, I7 de agosto de I976. . Eleição - Corrupção. Panfleto. Mundo Novo, 20 de novembro de 1976. . Caderno diário de um João Ninguém II. EA2.5.CVı.05.001, f.4r $\mathrm{r}^{\circ}$ e vo , 04.01.I977. . Alto Bonito.... Panfleto. Mundo Novo, I4 de julho de 1978. . Fim de papo. Panfleto. Mundo Novo, Io de julho de I982. . Caderno monitor. EA2.9.CVI.09.00I, f. 63v ${ }^{\circ}$, s.d. . Caderno monitor. EA2.9.CVI.09.00I. f. 69r ${ }^{\circ}$ e vo s.d.

O SERRINHENSE. Serrinha, 20 de novembro de I949, p. 3. 